\title{
腸疾患経過中に発生した下牛身麻痺の症例について
}

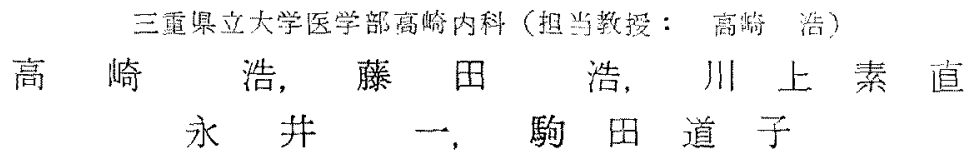

\section{CASES OF LOWER BODY PARALYSIS DEVELOPED DURING THE COURSE OF ENTEROCOLITIS}

\section{Hiroshi Takasaki, Hiroshi Fujita, Sunao Kawakami, Hajime NaGAI and Michiko Komada}

Department of Internal Medícine, Mie Prefectural University, School of Medicine

(Director: Prof. H. Takasaki)

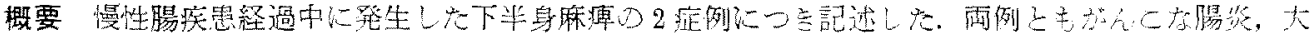

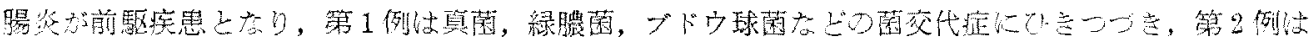

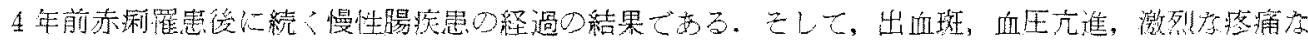

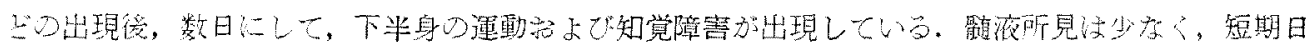

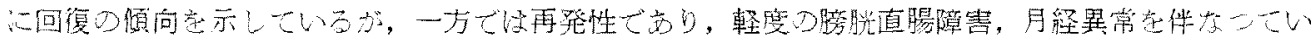

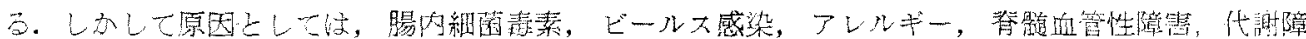

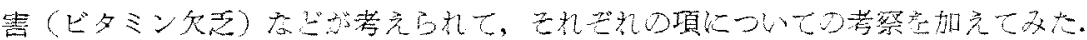

緒言

云染性腸疾患経過中に運動および知覚神経麻痺 を伴なう昰例については，Salmonella typhi や Shigella の感染症の場合, post-infectious myelitis (or myelopathy) の complication の女

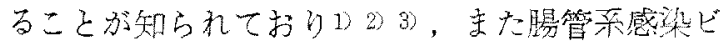
ールスである Polio, Coxackie, ECHO ビールフ のい势れもが向神経ビールスとして注目されてい る) 5).

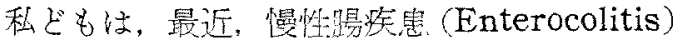
の経過中に，下半身の運動および知喾障害を来た した 2 症例学経験し，只の麻痺の症状およびその 他の神経系以外の症候群にも，汃的の共通点の 存在することを見出したのでこ〉に報告する。

症例

第 1 例.

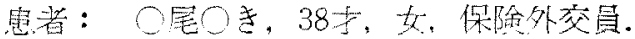

入院：1960年8月19日.

主訴：鼓踼および腹瘦。

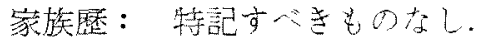

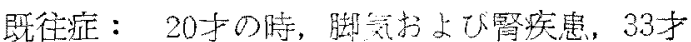
の時，于宮娞屈と副鼻腔焱の手術在うけている。

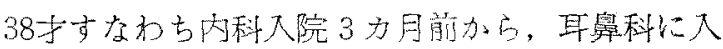
院し, 副鼻腔炎の再手術主门计, 術後, 每日, 又 イシリンの注射，サルファ到の投与を受けてい た。このころから腹痛および鼓晹があり，恶心， 食欲不振吉伴ない，最近をの程度索增加する傾向 がみられたので，内科机捏科して来たものである。

入院㭙現症：入院時，体格中等，栄荃や〉不 良, 体温 $37.5^{\circ} \mathrm{C}$, 平脈, 心肺異常なく, 腹部は鼓

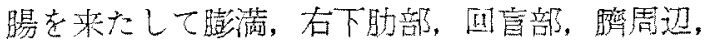
左僋腹部などに，日により大の場所と程度さ異に 


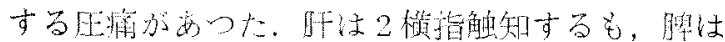

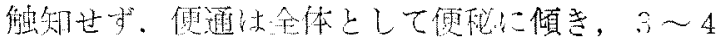

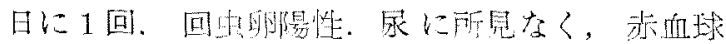

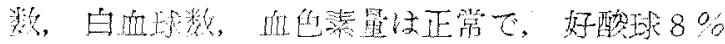

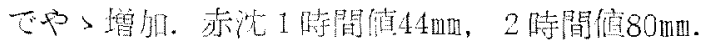

CRP隐性, A S LO 125 Todd 紧任. 血在115 65. 旰機能，Lugol 区広陽性なるもコンルト R3, T T T 2.0 u, 和 Cholesterol $247 \mathrm{mg} / \mathrm{dl}$, 撒

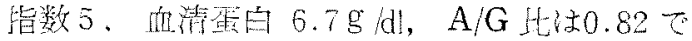

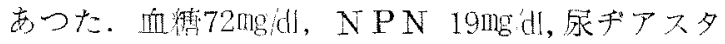

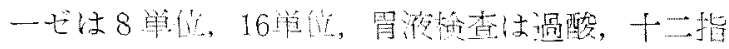

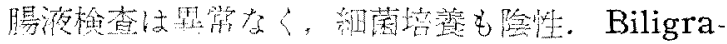

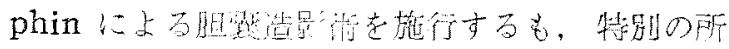
見はな斿った。

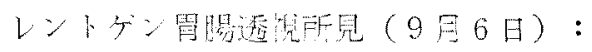

1）露には Nische および陸影欠提はなかつ たが, Gastroptose が諗放机た。

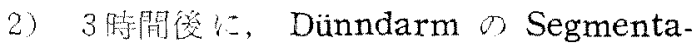

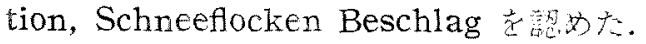

3) 㗱隻の Transversoptose があつた。

4) Dinndarm 占び Dickdarm には高席 $の$ Gas Ansammelung 悡好た。

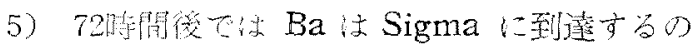
みであつた。

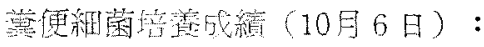

McConkey

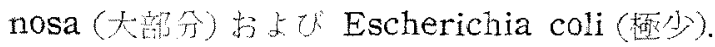

Sabraud 畦地八(Penicillin 抒よびSM含

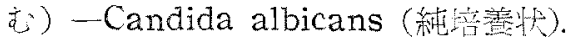

Thioglycollate 培地- -Pseudomonas aeruginosa (大频分) 拈上伯 Staphylococcus (一 部分).

Staphylo 110 培地一-Staphylococcus（大部 分) および Streptococcus (一站们).

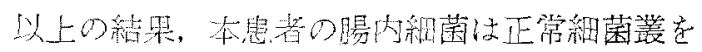
なす Escherichia 少なく、卧とんどが Pseudomonas aeruginosa, Candida albicans, Sta-

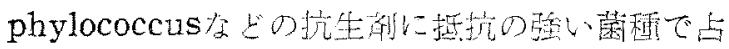

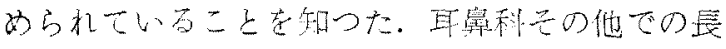

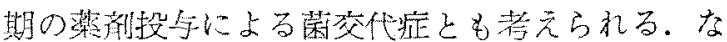
扮分离筷 Candida 株と鼠者血清との間に，スライ

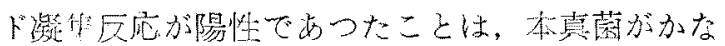

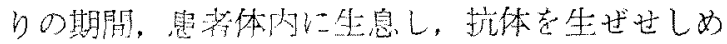
たるためと誟えたい。

麻湟の発現：以上の所㒻加らenterocolitisと 診断し, 各種整腸㨽, 蠕動促進绪, 鎮痛䘞, 強䀒

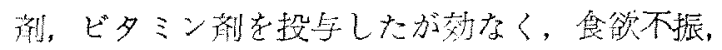

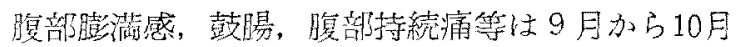
上旬に加次策に增瑟し，10月上旬上可次优心゙ るがごとき肖駆症状を呈し，約10日後，下半身の 椺痻を招来した（第 1 表）。

前駆症状。

(1) 疼痛一下肢から腹部諸筋にか子汓て，激烈な 後根刺激症状㥞疼痛を来たした。

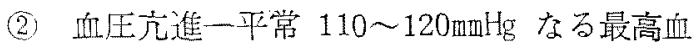

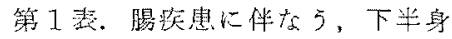

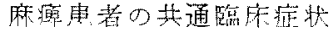

\begin{tabular}{|c|c|c|}
\hline & 1 例 & 2 例 \\
\hline 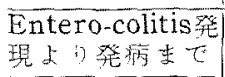 & $2 \sim 3$ 力 & $2 \sim 3$ 力 \\
\hline 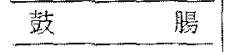 & + & \pm \\
\hline 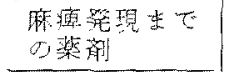 & $\begin{array}{l}\text { サルフォ剂, } \\
\text { マンショシ }\end{array}$ & $\begin{array}{l}\text { サルフっ削, } \\
\text { フラシジ }\end{array}$ \\
\hline 笔 & 鱉 & 梠 蓺 \\
\hline $\mathrm{EE}$ & 范進 & 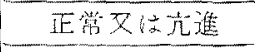 \\
\hline 出 lill 惊素回 & + & + \\
\hline 月䄱上心成保 & + & + \\
\hline 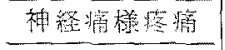 & + & + \\
\hline 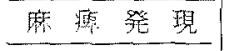 & 亜 檍 性 & 電 息 性 \\
\hline 库病発現の方向 & 杢梢上引中枢側人 & 本梢より中枢溉へ \\
\hline 筇 菱 䄼 & - & - \\
\hline 箭 緊 救 & 比較的弛緩性 & 比烄的㾤惊 \\
\hline 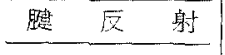 & PSRI，ASR消失 & PSR広進, ASRIE \\
\hline 罢 管 反 射 & - & 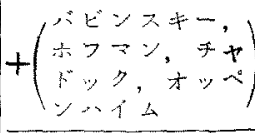 \\
\hline 知當障請 & $\begin{array}{l}\text { 知賞消失，中 } \\
\text { 枢側知覚過船 }\end{array}$ & $\begin{array}{l}\text { 知筧鈍磨 } \\
\text { 中根側知覚過敏 }\end{array}$ \\
\hline 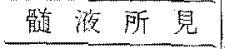 & 度 & 篔 \\
\hline 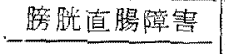 & 䔜 度 & 軽 度 \\
\hline F & $\begin{array}{l}2 \text { 週間以内に回 } \\
\text { 徨の傾向女り }\end{array}$ & 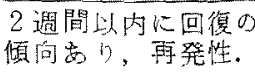 \\
\hline
\end{tabular}




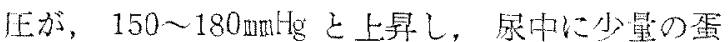
白を証明古るに至つた。

(3) 出血斑一下腿, 滕関節部”，大退に数コの直

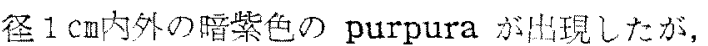
これはっ〜3日で消退した。

(4) しび机感一下肢天梢部加ら漱次上行性にし びれ感を来たし，下肢の泠感を訴えて来た。

(5) 体温，血液所見一大院当時加らの微熟は続

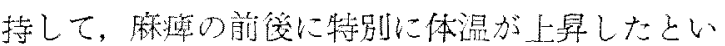
うこと名なく，主た血液所見も正常であつだ。

(6) 排便一因難上なつて, 浣腸, 便摘出術, ガ

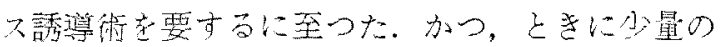
血洨，墙，粘液を混ずることもあつた。

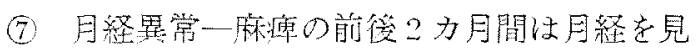
ていない。

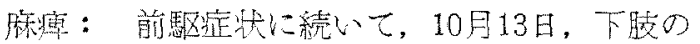
末梢部より，亜急性に，上行性の知覚および運動 麻瘦が現和れたが，麻瘁の上昇はや>不明暸に健

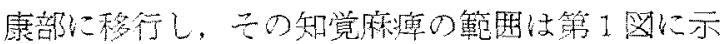
したと扔りである。

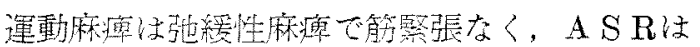
消失したが，PSRは正常であり，下肢の罢常反 射はことごとく院性であつた。腹壁反射は下部に おいて減弱また消消失していた。

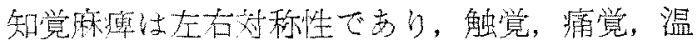
度覚，哚部知賞汪已もに完全に脱失していた。

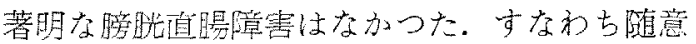

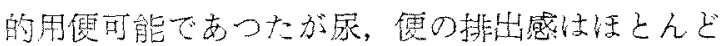
なく，また究全排出できず，残留感があると訴元

第工図。知喾買常的分布
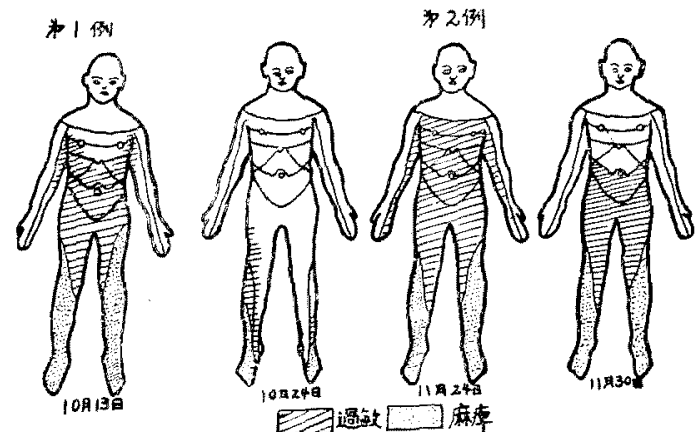

ていた，尿は頻尿て，1日12〜19间上增加した。

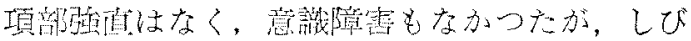
机感，管痛は上肢の高さまで達した。ご蛏度の 発語困難を挀えたが，似覚的に法正常でった。 軽度の强視や，耳鳴り，斯痛があつたが，一般に 脳神経の症状注汪とんどなかつた。

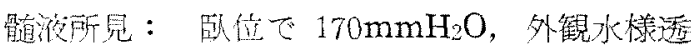
明. Sonnenstäubchenなし, 虽白 Pandy 枃陽 性. Nonne-Apelt 弱陽性。灌は Haines 法で正 常. 細胞数18/3 でリン・球. Queckenstedt $($-).

Wasserman 反庆陵性，一般細菌および真菌培 差隍性で，企般に所見は非常に軽微であつた。

Myelographie 所晃：後頭下案刺结上り造 影剂注入しなところ， $\mathrm{C}_{3} \sim \mathrm{C}_{6}$ で軽度点状にわ ずかに残存し，また $\mathrm{Th}_{10} \sim \mathrm{Th}_{12}$ で軽度ではあ るが， diffuse の Verwachsung あるごとき所

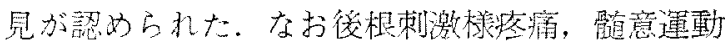

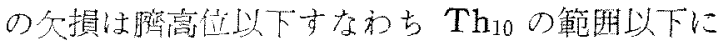
おいて著明でつた。

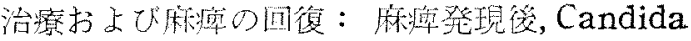
に上るガス発生索軽減するため，トリコマイシン

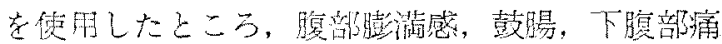
は数日にして著明に䊩快したが，さらにATP，

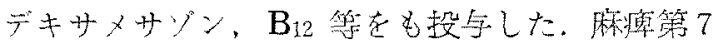
病日に，回復の储问走し，趾関節，足関節，滕 関節の随意運動が微留ながら可能となり，Sensibilität 导徐々に回復して来た。回復已同時に血 压名正常に復し，尿蛋白は隐性之なり，腹幖所見 も著明に改善された。10日後べッの上の起坐も 可能となり，40日後には起立も可能，45日後には

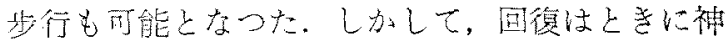
経痛槺疼痛，しびれ感索繰り返すが，階段的に治 㿈に向かつている。だ゙し低気玉や不連続線の通 過する前怯疼痛独骀くなようである。

第 2 例.

㭧者：○喜○美○子，31才，女，主婦.

入院：1960年10月27日。

主訴：下渎跶動麻瘦としびれ感。 


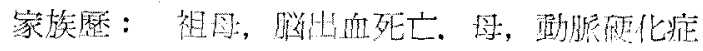
現存.

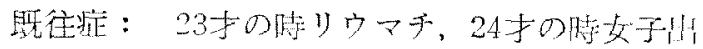

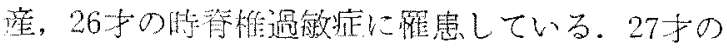

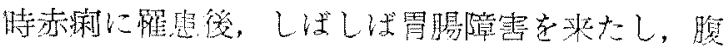

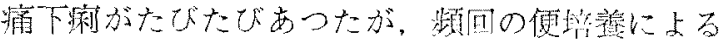

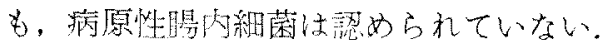

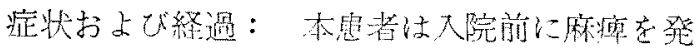
現しており，籍1例と基通した症状が多いので, その大要を筑1表に示してみた。その経過は，怍 年（1959年）8月ごろより，腹痛と粘泩便を来た し, Enterocolitis の䛦断のもとに治療要けて いたが，10月初旬，月経終了徬より，下肢に符痛 としびれ感㧍よび脱打感を訴えるようになり，加

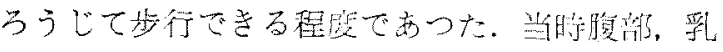

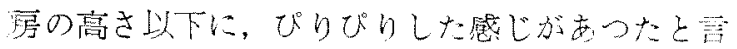

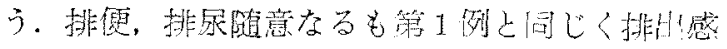
功なかつたそうであ。当病院外块診祭におい て，琏反射に变化なく，县常反射も認められず,

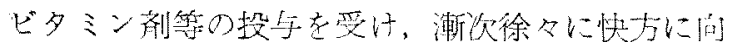

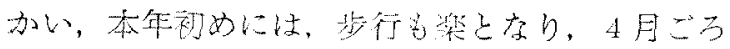

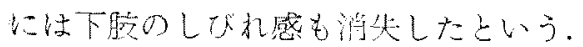

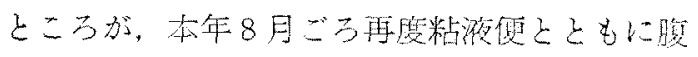

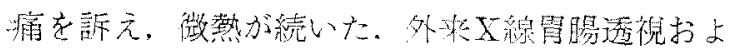
び注腸透視で，盟は ptotisch，小暘通過や，僬 く，上行去よび下行結淂の一部に spastisch

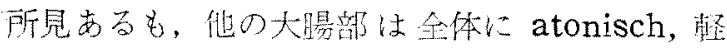
签の Transversoptose があつたが，Falten feinであつて, Ulcus の存在を思加せる像は なかつた．本所見加方 Colitis の䛦断のをとに， サルファ戍, プラジン，整腸剂，ビタミン剂等を 約 2 力月投与されている.10月18日月経終了後, 下胶しびれ感，符痛あり，脱力感著明で，起立， 步行ともに不可能となり，20日後には，下肢知覚 俚他覚的に鎮麻，腹部，胸部は逆に過敏挀えた。

PSR は元准し，ASR は正常，ハンスキーと オッペン八イムは陽性，血杘は 118７0と正常で 要つたが，第 1 例と同じく下腿部に出血斑 $3 〜 4$ コ出現したので10月27日精查の目的で大院した。

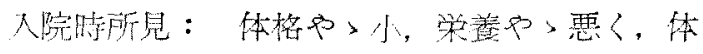
温 $37.3^{\circ} \mathrm{C}$, 平脈, 心肺異常なく, 腹部㕸柽度の鼓 晹上ともに大腸の走行に沿つ下不痛必亦つた。䀒

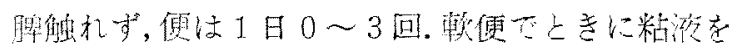

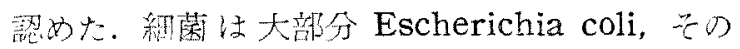

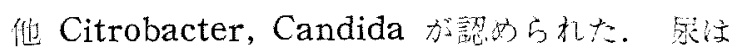
蛋白弱陽性の洼加異管なく，血液所見正常，赤沈

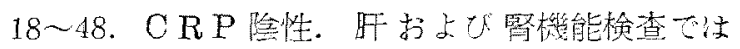
Lugol 区応陽性. コバルト Ro, T T T 1.2u., cholesterol $170 \mathrm{mg} / \mathrm{dl}$, 血清整白 $7.2 \mathrm{~g} / \mathrm{dl}, \mathrm{A} / \mathrm{G}$ 比1.31, N P N 28mg/dl, Urea N 14.3mgであっ 大。霄液は低酰，Wasserman 巨応陰性で市

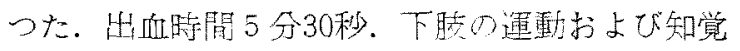
異常注前記の上おりであつた。顝洨所見は細胞数 9/3, リンパ球. Nonne-Apelt (-). Pandy (士). 液压 $120 \mathrm{mmH}_{2} \mathrm{O}$. $3 \mathrm{cc}$ 排液得 $90 \mathrm{mmH}_{2} \mathrm{O}$. Que-

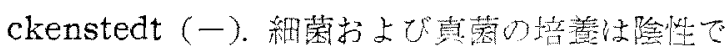
あつた。

入院後経過：入院得，力りクレン，ATP， アリナミン，アドナ然の治療を行なつたとこう，

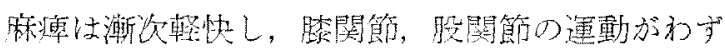
加に何能となつて来たが，11月10日，再び，下腿に

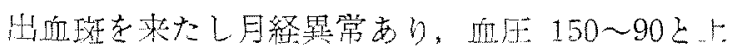

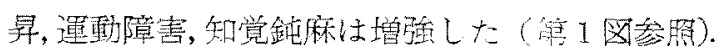

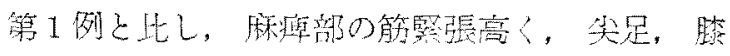

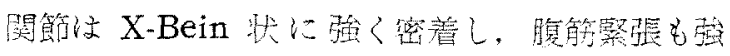
い.また罢常区射が陽性である。䏽胱植晹障呈 は同程度であるが、第1例のご上宗完全知覚消失 は一度も来たしていない. Myelographie て, $\mathrm{C}_{6} \sim \mathrm{C}_{7}$ に Cervical Hernia の残留哂めなが，現症の所是已位置的に会致し 難いるうに思う。しかし麻瘵は第1国に示すごと く，徐水快方に向加つている。

\section{考案}

以上 2 列に尔いて顕著な共通点等げてみる と，晹炎，大晹炎が前駆疾㭧上して存在し，2例 とも女で月経暴常と関倸あり，麻瘦の起こる朔に 出血斑の出現，血压六進，被経痛様筋痛があり，

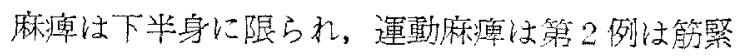




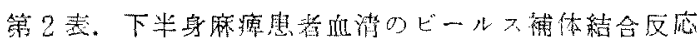

\begin{tabular}{|c|c|c|c|c|c|c|c|c|c|c|c|c|c|c|}
\hline \multirow{2}{*}{ 患 } & \multirow{2}{*}{\multicolumn{2}{|c|}{$\begin{array}{l}\text { 著 } \\
\text { 蜺 }\end{array}$}} & \multirow{2}{*}{ 抗 } & \multirow{2}{*}{$\sqrt{l^{\prime}}$} & \multicolumn{3}{|c|}{ 血 } & 湆 & \multicolumn{2}{|c|}{ 稀 } & \multicolumn{2}{|l|}{ 积 } & \multicolumn{2}{|c|}{ 刘 貾 } \\
\hline & & & & & 2 & 4 & 8 & 16 & 32 & 64 & 128 & 256 & $N$ & S \\
\hline \multirow{4}{*}{ 第 } & \multirow{4}{*}{1} & \multirow{4}{*}{ 约 } & 我! & I & & 2 & 2 & 1 & 1 & 0 & & & 0 & 0 \\
\hline & & & & II & & 2 & 2 & 2 & 0 & 0 & & & & \\
\hline & & & & II & & 0 & 0 & 0 & 0 & 0 & & & & \\
\hline & & & Coxa & & & 0 & 0 & 0 & 0 & 0 & & & & \\
\hline \multirow{4}{*}{ 第 } & \multirow{4}{*}{2} & \multirow{4}{*}{19} & +1 & I & & 0 & 0 & 0 & 0 & 0 & & & 0 & 0 \\
\hline & & & & II & & 0 & 0 & 0 & 0 & 0 & & & & \\
\hline & & & & III & & 0 & 0 & 0 & 0 & 0 & & & & \\
\hline & & & Coxa & & & 0 & 0 & 0 & 0 & 0 & & & & \\
\hline
\end{tabular}

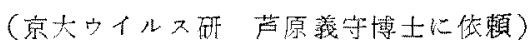

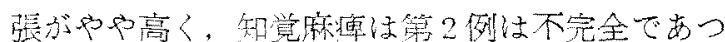
たか，耐例上も，数週以内で回復の傾问を示し，

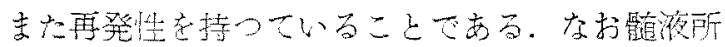

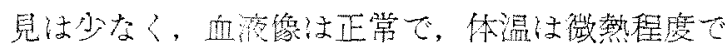

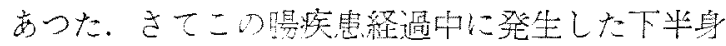

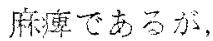

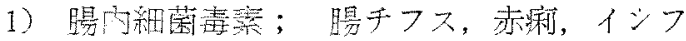

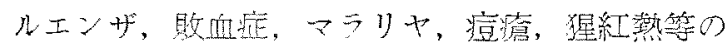

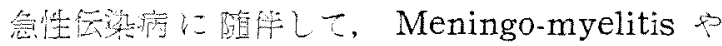

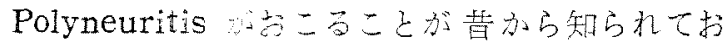

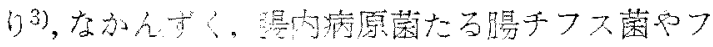

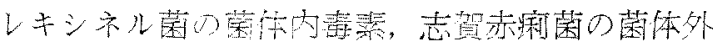

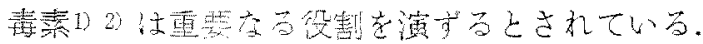

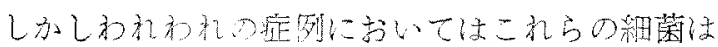

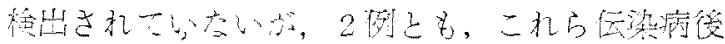

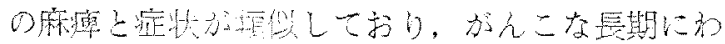

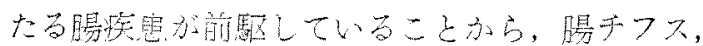

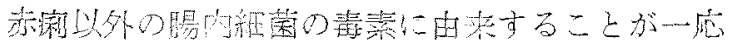

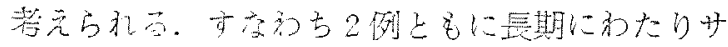

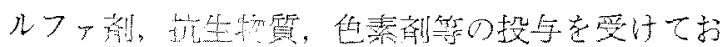

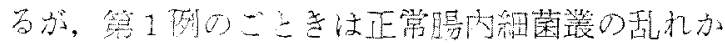
$\zeta$, Candida albicans p Pseudomonas aeru-

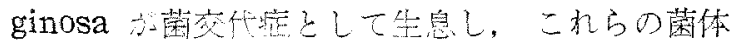

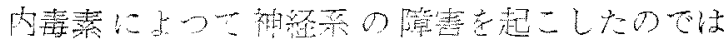
ない咕う力。十りコマイシンに上る眼症状の改

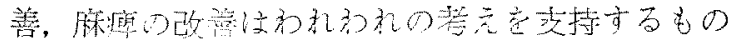
の上うでる。

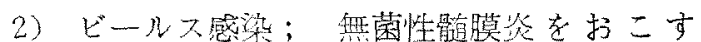
ビールスとして，ムンプス，LCM, ルルペス，狂

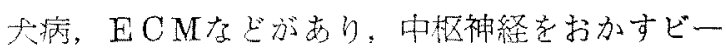
ルスとして，日本酰，ボリ才，コクザッ一,

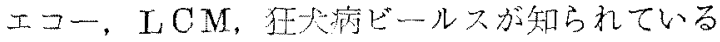

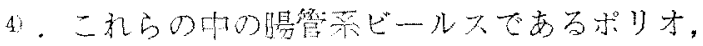

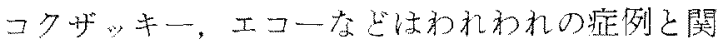

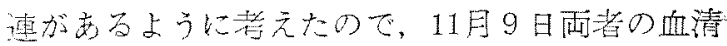
㧻取し，Polio I,II,III 型㧍よで Coxackie ビ

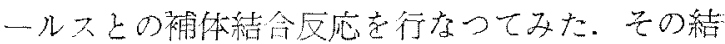

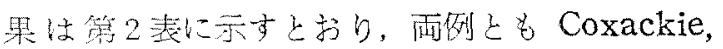

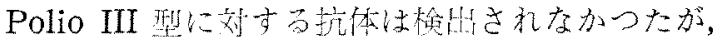

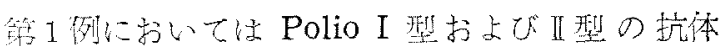

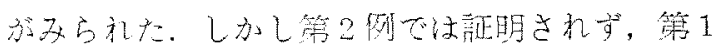

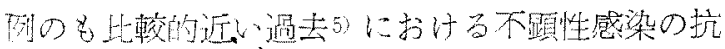

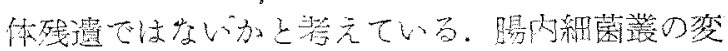

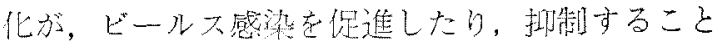

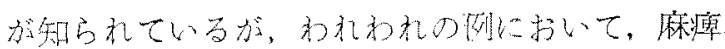

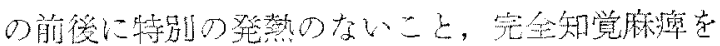

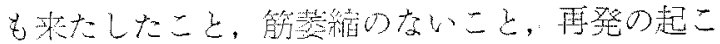

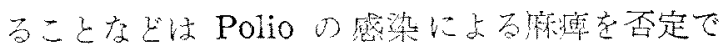

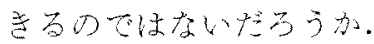

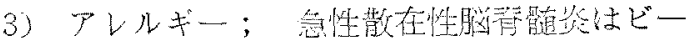

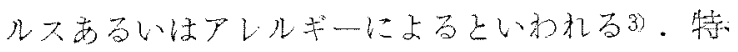

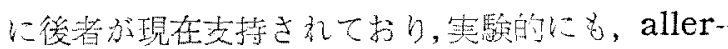

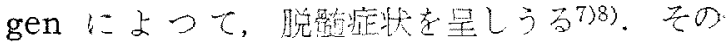

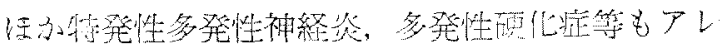




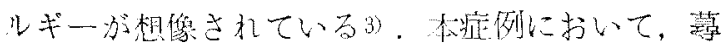

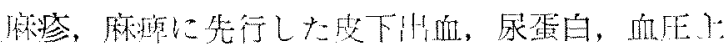
界等分雨例上もに現加机たこと注，アレルギ一性

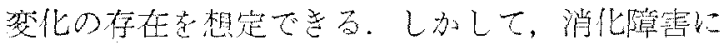

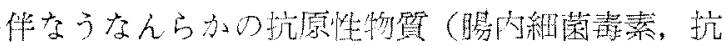
原化した組織蛋白なだ）による感作，あるいはな

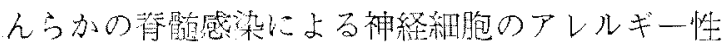
罗化などが相像される。

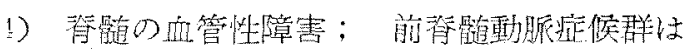
㧍もに腰䯣を中心として㧍こり,鋭い痛みがあり，

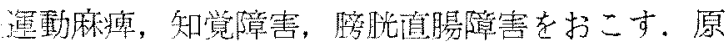
因は梅毒や動脈硬化症が多いが，原因不明のもの や，機能的の血行障害者考光られている3６．わ 施

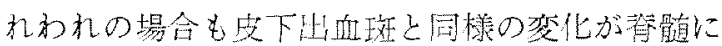
発生したここ圭否定できない，血压上昇，再発性

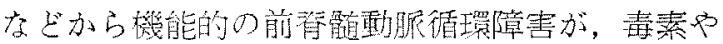
アレルギー等の原因で起こつたとも考えられる。

万) 代謝障害，ビタミンの缺无；神経組織に

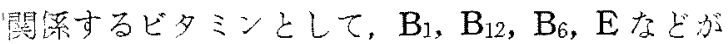
ありまたパントテン酸も衴経䋎織に影響がある と言われている3。出血性䋜因に関して C,K,P

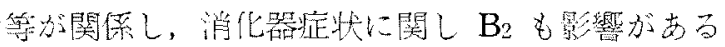
己思われる3。二の隹栄養素の不足に，神経組

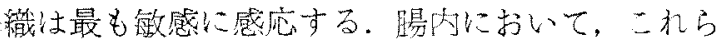
栄荃素の吸收注もちろん，西当棰ビタミンの合成 や破壊が行なわ扎ている，本症例のごとく，慢性 腸疾患の存在により，正常大腸菌なぞによるビ夕 ミンの合成が行なわれず，また菌交代症によるビ

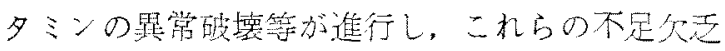
当本症の原因として考え衫代ならない。

以上五つの原因を举代てみたが，浃定的にこれ

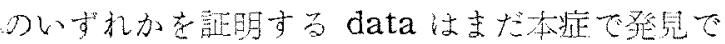

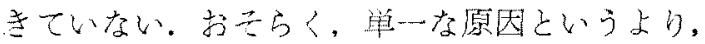

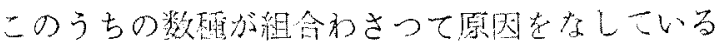
ものと想像される。

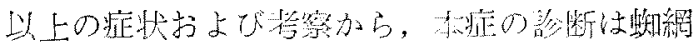

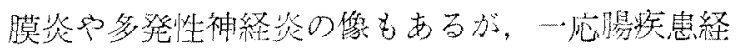
過印に起こつた奨船炎ではないだるうか。

\section{結論}

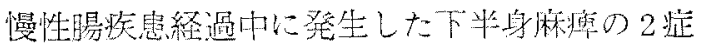
例につき記述した。両側ともがんこな腸桨，大陽 炎が前駆疾㭧となり，第1例は真菌，緗澧菌，フ ド宁球菌等の菌交代症にけきつづき，第2列は4 年前赤症恽息後心続く慢性腸疾息の経過の結果で ある。そして，出血斑，血在克焦，激烈な疼痛な どの出現後，数日にして，下半身の連動ちよび知 覚障害が出現している。髄液所見は少なく，短期 日に同復の傾问を示しているが，一方で再発性

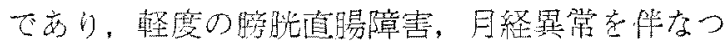
ている。

しふして原因としては, 腸内細菌毒素, ビール

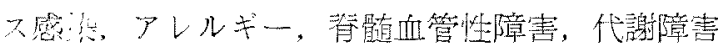

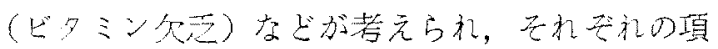
についての考察を加えてみた。

\section{昭和35年 12 月 3 日 \\ 需61回象海地方会推萀}

\section{文献}

1) Olitsky, P.K. and Kligler, I.J.: J. Exper. Med., 31 : 19, 1920. -2) Boroff, D.A.: J. Bact., $57: 617,1949$. 一 3) 現代内科学大䒺: 感染症 II,

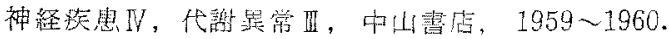
-4）徐监一郎：テダンィディフ，7：2，1961. -

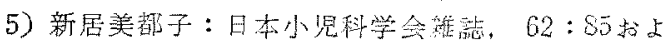
び 1262, 1958, - 6) 加政洋, 岡田次堆。古田和 夫, 祖父江逸郎：鼠新医学, $14: 1079,1959$ 。一 7) Finley, H.K.: Arch. Neurol. \& Psychiat., $39: 1047,1938.37: 505,1937 . \quad$ - 8) Kabat, E.A., Wolf, A. \& Berzer, A.E.: J. Exper. Med., $85: 117,1947$. 